\title{
ANALISIS RISIKO PADA RANTAI PASOK SUSU: SEBUAH PENDEKATAN MODEL BERBASIS AGEN
}

\author{
Andre Rivianda Daud', Utomo Sarjono Putro', Manahan Siallagan', dan \\ Dhanan Sarwo Utomo ${ }^{2}$ \\ ${ }^{1}$ Sekolah Bisnis dan Manajemen Institut Teknologi, Bandung \\ ${ }^{2}$ Lancaster University Management School \\ Email: andre.r.daud@unpad.ac.id
}

\begin{abstract}
ABSTRAK. Usaha-usaha pertanian pada umumnya menghadapi banyak risiko dan ketidakpastian. Hal ini mengharuskan para pelaku usaha pertanian untuk membuat banyak keputusan produksi dibawah tekanan risiko tersebut. Oleh karena itu, keberadaan risiko diperkirakan memiliki keterkaitan yang erat dengaan kinerja produksi. Penelitian ini bermaksud untuk mengidentifikasi sumbersumber risiko di dalam usaha sapi perah serta memperkirakan dampaknya terhadap kinerja rantai pasok susu secara keseluruhan. Survey telah dilakukan di wilayah produksi susu sapi di Kabupaten Bandung dalam periode bulan Oktober sampai dengan Desember tahun 2016. Data diperoleh melalui wawancara terhadap 154 peternak sapi perah di wilayah tersebut. Sumber-sumber risiko ditentukan dengan menggunakan teknik analisis komponen pokok (PCA), sementara perkiraan dampaknya terhadap kinerja produksi diperoleh melalui pemodelan berbasis agen (ABM). Hasil analisis menunjukkan bahwa faktor yang dianggap paling signifikan dalam mempengaruhi kinerja produksi adalah risiko menurunnya ketersediaan sumberdaya pakan dari waktu ke waktu. Berdasarkan simulasi model, faktor ini diyakini juga menjadi pemicu timbulnya faktor-faktor risiko lainnya. Kondisi ini menunjukkan bahwa hampir seluruh risiko yang ada di dalam rantai pasok susu berkaitan antara satu dan lainnya secara sistemik. Sebagai implikasinya, pengelolaan risiko rantai pasok susu tidak dapat dilakukan secara parsial melainkan holistik.
\end{abstract}

Kata kunci: peternak, sapi perah, kinerja, simulasi

\section{ANALYSIS OF RISKS IN MILK SUPPLY CHAIN: AN AGENT BASED MODEL APPROACH}

\begin{abstract}
Agricultural business generally face many risks and uncertainties. This requires farmers to make many production decisions under the pressure of such risks. Therefore, the existence of risk is expected to have a close relationship with production performance. This study intends to identify the sources of risk in the dairy farming and estimate its impact on overall performance of milk supply chain. Survey have been conducted in the dairy cattle production area in Bandung regency in the period of October to December 2016. Data were obtained through interviews of 154 dairy farmers in the particular region. Risk sources are determined using principal component analysis techniques (PCAs), while estimates of their impact on production performance are obtained through agent-based modeling (ABM). The result shows that the factor that is considered in significantly influencing the production performance is the risk of decreasing the availability of feed resources from time to time. Based on the model simulation, this factor is also believed to trigger the emergence of other risk factors. This condition indicates that almost all of the risks in the supply chain are linked systemically to one another. As the implication, the risk management of milk supply chain can not be done partially but in a such holistic way.
\end{abstract}

Key word: farmer, dairy cattle, performance, simulation

\section{PENDAHULUAN}

Usaha peternakan pada umumnya merupakan suatu bisnis yang memiliki risiko produksi dan ketidakpastian yang cukup besar karena sangat berkaitan dan rentan terhadap dinamika lingkungan, baik lingkungan biofisik ataupun ekonomi. Secara biofisik, usaha peternakan sangat dipengaruhi setidaknya oleh kondisi klimatologis dan ketersediaan sumberdaya alam pendukung, sementara produk-produknya sangat dipengaruhi oleh situasi ekonomi, seperti naik turunnya pasokan-permintaan (supply-demand), variabilitas harga pasar, kebijakan perdagangan serta variabelvariabel ekonomi lainnya. Dengan karakteristik tersebut, para pelaku usaha peternakan tentunya akan sangat mempertimbangkan keberadaan berbagai risiko tersebut pada setiap proses pengambilan keputusan produksi, serta pada gilirannya akan berdampak pada kinerja usahanya secara keseluruhan. Oleh karena itu, secara akademis, informasi mengenai sumber-sumber risiko dan respon pelaku terhadapnya menjadi elemen yang esensial di dalam memahami kinerja sebuah usaha peternakan.

Sapi perah merupakan salah satu komoditas ternak yang lazim diusahakan dalam skala pemeliharaan yang kecil oleh masyarakat pedesaan di Indonesia. Hingga saat ini, usaha sapi perah tersebut setidaknya telah memberikan kontribusi pada produksi pangan (susu dan daging sapi), menghasilkan pendapatan bagi pemeliharanya, serta menjadi aset hidup (living asset) yang bersifat sangat likuid bagi rumahtangga pedesaan. Namun disamping banyaknya potensi tersebut, fakta menunjukkan bahwa produktivitas usaha sapi perah 
secara umum cenderung mengalami penurunan. Hal ini dapat terlihat dari semakin berkurangnya populasi ternak, produksi susu serta pelaku usaha peternakan sapi perah di wilayah-wilayah sentra produksi (Daud, Putro \& Basri, 2015; Mauludin, 2017). Sebagai salah satu contoh empirik, laju penurunan populasi ternak dan pelaku usaha sapi perah di wilayah sentra sapi perah di Kabupaten Bandung tercatat mencapai kisaran 12-12.5\% per tahun (KPBS, 2016). Penelitian ini berargumen bahwa keberadaan risiko serta respon pelaku usaha terhadap risiko tersebut memberikan kontribusi yang tidak kecil terhadap naik turunnya produktivitas usaha ternak.

Risiko pada usaha sapi perah telah banyak dijadikan topik utama oleh banyak penelitian terutama di negara-negara produsen komoditas pertanian. Namun di dalam konteks usaha peternakan di negara berkembang yang sebagian besarnya dijalankan dengan polatradisional, penelitian tentang risiko dan pengelolaannya masih belum banyak dilakukan. Fakta menunjukkan bahwa realita ekonomi sosial dan lingkungan di negara berkembang sangat berbeda dengan negara maju sehingga hasil-hasil penelitian tersebut tidak dapat digeneralisasi. Selain itu, hingga saat ini, sebagian besar penelitian - baik pada usaha-usaha peternakan atau lainnya - mengasumsikan bahwa risiko merupakan sesuatu yang bersifat statis. Asumsi ini sepertinya tidak dapat berlaku lagi pada saat ini dimana terdapat perubahan-perubahan yang terjadi sangat cepat dan dinamis. Perubahan-perubahan inilah yang diyakini menjadi motor kemunculan sumber dan jenis risiko yang sama sekali baru yang harus dihadapi oleh dunia peternakan (Mishra \& Shekhar, 2011).

Oleh karena itu, penelitian ini bermaksud untuk (i) mengidentifikasi sumber-sumber risiko di dalam usaha sapi perah; dan (ii) memperkirakan pengaruh dari keberadaan berbagai risiko tersebut terhadap kinerja rantai pasok susu. Tujuan utama dari penelitian ini adalah menghasilkan sebuah model yang dapat memperlihatkan keterkaitan antar risiko dan kinerja pada usaha sapi perah ataupun sistem rantai pasok susu secara keseluruhan. Hasil penelitian ini diharapkan dapat menjadi sebuah informasi akademis bagi para pengambil kebijakan terkait strategi pengelolaan risiko pada usaha-usaha peternakan.

\section{METODE}

Penelitian ini telah dilaksanakan di wilayah kerja Koperasi Peternak Sapi Perah Bandung Selatan (KPBS) di Kabupaten Bandung pada periode bulan Oktober-Desember 2016. Wilayah penelitian ditentukan secara sengaja dengan pertimbangan bahwa wilayah ini merupakan salahsatu sentra usaha produksi susu sapi yang terbesar secara nasional. Tipe penelitian ini adalah deskriptif dengan survey sebagai strategi utama pengumpulan data dan informasi (Saunders \& Lewis,
2008). Survey dilakukan kepada 154 orang peternak yang terpilih sebagai contoh (sample). Peternak contoh ditentukan secara berjenjang (stratified random sampling) melalui pengelompokkan berdasarkan wilayah Tempat Pelayanan Koperasi (TPK) yang kemudian selanjutnya dipilih secara acak (random) di dalam masingmasing TPK. Berdasarkan pertimbangan ketersediaan sumberdaya penelitian, jumlah peternak yang dijadikan contoh adalah sebesar 5\% dari jumlah total peternak sapi perah yang berada di wilayah ini ( \pm 3000 peternak). Data primer dan informasi yang digunakan oleh penelitian ini diperoleh melalui pengisian kuisioner terpandu (administered questionairre) oleh para peternak contoh terpilih tersebut, sementara data sekunder diperoleh terutama dari KPBS sebagai mitra utama peternak sapi perah di dalam rantai pasok susu. Sejalan dengan maksud untuk mengidentifikasi sumber-sumber risiko pada usaha sapi perah, serta memodel berbagai risiko tersebut untuk memperkirakan dampaknya terhadap kinerja produksi secara keseluruhan, maka metode analisis data yang digunakan masing-masing adalah principal component analysis (PCA) (Meuwissen, Huirne \& Hardaker, 2001; Akcaoz, Kizilay \& Ozcatalbas, 2009) dan pemodelan berbasis agen (agent based modeling - ABM) (Daud, Putro \& Utomo, 2013).

Metode PCA digunakan untuk mengidentifikasi beberapa variabel yang memiliki pola dan sifat yang sama, kemudian masing-masing "dilebur" menjadi sebuah atau banyak faktor (Abdi \& Williams, 2010) melalui prosedur penghitungan sebagai berikut: (i) penghitungan matriks covariance dari berbagai variabel yang dipertimbangkan; (ii) penentuan nilai eigenvectors dan eigenvalue; (iii) penghitungan bobot faktor (factor loading); dan (iv) penentuan faktor. Merujuk pada Flaten et.al (2005) dan Zhou, Nanseki \& Takeuchi (2012), terdapat setidaknya 30 variabel di dalam usaha sapi perah yang dapat dipertimbangkan sebagai sumber risiko; tercakup ke dalam 5 kategori: produksi, pemasaran, finansial dan teknologi. Pada survey, peternak contoh diminta informasinya mengenai seluruh variabel tersebut melalui serangkaian penilaian di dalam bentuk skala Likert. Skala ini memiliki rentang dari nilai 1 sampai dengan 5; dimana nilai 5 menunjukkan sumber risiko yang dianggap signifikan bagi peternak sapi perah, sementara nilai 1 menunjukkan sumber yang tidak dianggap signifikan. Sebelumnya, uji Kaiser-Meyer-Olkin (KMO) untuk menentukan layak tidaknya PCA diaplikasikan pada data yang tersedia (Chow, 2004). Nilai KMO bervariasi antara 0 dan 1 , dimana data dengan nilai lebih dari 0.5 dianggap layak untuk dianalisis dengan menggunakan PCA.

Setelah sumber-sumber risiko yang signifikan dapatdiidentifikasi, analisisdilanjutkan denganpemodelan untuk mengestimasi dampaknya terhadap kinerja produksi usaha sapi perah dan rantai pasok susu. ABM digunakan untuk menggambarkan dan mensimulasikan berjalannya sebuah sistem yang terdiri dari satu atau 


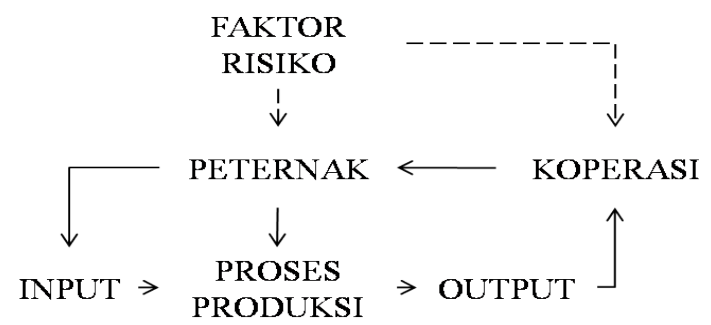

Gambar 1. Konsep model risiko berbasis agen pada rantai pasok susu

banyak elemen (agen). Macal dan North (2008) dan Chen et. al (2013) secara ringkas mendefinisikan agen sebagai variabel yang (i) memiliki perilaku dan kemampuan untuk membuat keputusan; (ii) otonom dan terarah (selfdirected); (iii) dapat berinteraksi dengan variabel / agen lainnya dalam sistem; (iv) mempunyai tujuan (goal directed); dan (v) bersifat fleksibel sehingga mampu beradaptasi melalui perubahan perilaku. Di dalam penelitian ini, rantai pasok susu diasumsikan memiliki dua pelaku (agen) utama, yaitu peternak sapi perah yang berperan sebagai produsen susu sapi, dan koperasi sebagai lembaga bisnis yang berperan sebagai konsumennya. Setiap agen memiliki atribut (peran) yang berbeda. Agen peternak memilki atribut yang terdiri dari (i) memelihara ternak dan memproduksi susu; (ii) mencari pakan ternak; serta (iii) menjual dan membeli ternak, sementara atribut koperasi adalah (iv) membeli hasil produksi peternak dan (v) menentukan harga beli berdasarkan grading kualitas susu. Secara umum, model risiko ini memperlihatkan dinamika perubahan atribut masing-masing agen yang disebabkan oleh interaksi keduanya dibawah keberadaan risiko. Hasil (output) perubahan seluruh atribut tersebut diindikasikan oleh berbagai parameter, baik parameter teknis ataupun finansial. Adapun paramater yang diamati adalah: (i) jumlah peternak di wilayah yang bersangkutan; (ii) jumlah kepemilikan ternak per peternak (skala usaha); (iii) produktivitas sapi perah; (iv) kualitas susu; (v) tingkat pendapatan peternak; (vi) total jumlah susu yang dapat dibeli oleh koperasi; dan (vii) kondisi finansial koperasi. Pemodelan risiko dan simulasinya dilakukan dengan menggunakan perangkat lunak NetLogo versi 6.0.1.

\section{HASIL DAN PEMBAHASAN}

\section{Sumber-sumber Risiko pada Rantai Pasok Susu}

Hasil analisis menunjukkan bahwa setidaknya terdapat sebelas faktor risiko yang dapat mempengaruhi produksi usaha sapi perah secara signifikan. Sebelumnya, uji KMO menghasilkan nilai sebesar 0.62 ; mengindikasikan bahwa data terhitung cukup layak (mediocre) untuk dianalisis dengan metode PCA. Secara statistik, tiap-tiap faktor memberikan kontribusi sebesar antara 3-13\% terhadap variasi produksi. Hal ini berarti bahwa jika kontribusi risiko terhadap produksi dapat dikuantifikasi, maka seluruh faktor-faktor dapat mempengaruhi variasi produksi sebesar kumulatif $66 \%$. Tabel 1 dibawah ini memperlihatkan seluruh faktor risiko yang disertakan di dalam analisis dan hasil perhitungan bobotnya masing-masing.

Berdasarkan bobot faktornya, faktor risiko pertama (F1) yang sangat mempengaruhi usaha sapi perah $(13.6 \%)$ adalah pakan; baik pakan hijauan (sebagai makanan utama ternak) ataupun pakan konsentrat (makanan tambahan). Pada hijauan, ketersediaan dan kualitas pada faktanya tengah menjadi masalah bagi usaha sapi perah. Seiring dengan tingginya laju konversi lahan di sekitar wilayah peternakan, ketersediaan hijauan pun cenderung menurun antar waktu. Keterbatasan lahan sumber hijauan juga menyebabkan eksploitasi berlebih pada lahan-lahan yang tersisa sehingga hijauan yang dihasilkan pun berkualitas rendah. Aspek rendahnya kualitas konsentrat juga menjadi isu utama di dalam pemenuhan kebutuhan pakan karena pada faktanya standar kualitas pakan konsentrat samasekali belum diterapkan oleh produsen pakan. Pada usaha sapi perah, rendahnya ketersediaan dan kualitas pakan direspon dengan tidak optimalnya kuantitas dan kualitas susu sapi yang dihasilkan.

Faktor risiko yang kedua (F2) berkaitan dengan kualitas genetik dan reproduksi sapi yang dipelihara. Secara teknis, kualitas dapat terlihat dari produksi susu, lama periode produksi, dan jarak beranak (calving interval); dimana ketiga aspek ini saling berkaitan. Di dalam konteks peternakan berskala kecil, sapi dengan produksi susu sebanyak 15-20 liter per hari, berproduksi selama 10 bulan per tahun dan jarak beranak 12-13 bulan dianggap sebagai genetik yang ideal. Namun pada faktanya, sebagian besar sapi perah yang diusahakan oleh para peternak memiliki kualitas yang sub-ideal. Hal ini berkaitan belum terdapat pasar atau lembaga yang menyediakan ternak dengan kualitas genetik tertentu, sehingga peternak biasanya tidak mempunyai informasi yang cukup mengenai kualitas genetik, terutama pada saat pembelian ternak sebagai input produksi. Hal ini juga beredampak pada ketidakpastian ketersediaan dan harga ternak terutama bibit induk pengganti sehingga menjadi risiko tersendiri yang harus dihadapi oleh para peternak (F9).

Faktor risiko ke tiga (F3) berkaitan dengan hubungan antara peternak dengan mitra usahanya yaitu koperasi dan sesama peternak. Secara spesifik, hal ini berkaitan dengan penentuan harga beli susu oleh koperasi. Pada saat penelitian ini dilaksanakan, penentuan harga susu oleh koperasi ditentukan berdasarkan kualitas susu secara kolektif dan bukan secara individu. Produksi susu yang dihasilkan oleh seluruh peternak di dalam satu wilayah produksi ditampung secara kolektif di dalam cooling unit tertentu, kemudian baru ditentukan nilai harganya. Kesenjangan muncul ketika susu dengan kualitas relatif tinggi disatukan dengan yang berkualitas lebih rendah sehingga harga beli yang ditentukan oleh 
Analisis Risiko pada Rantai Pasok Susu: Sebuah Pendekatan Model Berbasis Agen

(Andre Rivianda Daud, Utomo Sarjono Putro, Manahan Siallagan, dan Dhanan Sarwo Utomo)

Tabel 1. Sumber-sumber risiko dan bobot faktor

\begin{tabular}{|c|c|c|c|c|c|c|c|c|c|c|c|}
\hline \multirow{2}{*}{ Sumber-sumber Risiko } & \multicolumn{11}{|c|}{ Faktor } \\
\hline & F1 & F2 & F3 & F4 & F5 & F6 & F7 & F8 & F9 & F10 & F11 \\
\hline Kualitas pakan hijauan & .83 & .21 & & & & & & & & & \\
\hline Ketersediaan pakan hijauan & .75 & .22 & & & & & & & & & .10 \\
\hline Kualitas pakan konsentrat & .51 & & .27 & .12 & .36 & -.12 & & & .21 & .23 & \\
\hline Harga pakan konsentrat & -.43 & & .18 & & .41 & -.21 & -.14 & & & & -.38 \\
\hline $\begin{array}{l}\text { Produksi susu per } \\
\text { ekor }\end{array}$ & & .78 & .11 & & .11 & & -.12 & & & & \\
\hline Calving interval & .21 & .74 & .15 & .13 & & & .10 & & & & \\
\hline Periode lama laktasi & .44 & .55 & & & -.20 & & & & & .34 & \\
\hline Kondisi kesehatan hewan & .31 & .39 & -.11 & & .15 & .22 & & -.27 & & .39 & \\
\hline Praktik penanganan susu & .31 & .34 & .31 & .15 & .27 & & & -.26 & -.20 & -.23 & .21 \\
\hline Sistem penentuan kualitas susu & -.15 & .12 & .79 & -.11 & .12 & & & & & & .14 \\
\hline $\begin{array}{l}\text { Hubungan sosial sesama } \\
\text { peternak }\end{array}$ & .15 & .10 & .78 & .10 & -.16 & -.12 & & -.14 & & & -.12 \\
\hline $\begin{array}{l}\text { Kesinambungan pasokan } \\
\text { konsentrat }\end{array}$ & .51 & & .55 & & & .11 & & -.18 & & & -.14 \\
\hline $\begin{array}{l}\text { Minat tenaga kerja pada usaha } \\
\text { ternak }\end{array}$ & & & & .87 & .14 & & & & & & \\
\hline $\begin{array}{l}\text { Ketersediaan tenaga kerja } \\
\text { upahan }\end{array}$ & -.12 & .20 & & .84 & & & & .10 & & & \\
\hline Tingkat upah tenaga kerja & .12 & -.14 & .12 & .52 & .26 & .16 & -.30 & & & .40 & \\
\hline $\begin{array}{l}\text { Tuntutan kualitas susu dari } \\
\text { pembeli }\end{array}$ & -.23 & .18 & & & .67 & & -.18 & -.25 & -.16 & -.16 & .14 \\
\hline $\begin{array}{l}\text { Nilai tukar produk lain } \\
\text { (hortikultura) }\end{array}$ & & -.10 & -.14 & .11 & .57 & .13 & .12 & & & & \\
\hline Harga susu di tingkat peternak & .21 & & .15 & .30 & .56 & & -.14 & & & .33 & -.19 \\
\hline Ketersediaan skema kredit & & & -.28 & -.16 & .50 & & .19 & .21 & .44 & & \\
\hline $\begin{array}{l}\text { Ketersediaan penerus usaha } \\
\text { ternak }\end{array}$ & & & & & .13 & .75 & & & & -.18 & -.15 \\
\hline Kenaikan harga-harga umum & -.36 & & & & .24 & -.59 & & & -.27 & -.17 & -.25 \\
\hline $\begin{array}{l}\text { Kapasitas pengolahan limbah } \\
\text { ternak }\end{array}$ & & & .30 & & & & .79 & -.11 & & & \\
\hline $\begin{array}{l}\text { Kebijakan atau peraturan } \\
\text { pemerintah }\end{array}$ & & & -.20 & & & .10 & .77 & & & & \\
\hline $\begin{array}{l}\text { Umur produktif dan kondisi } \\
\text { kesehatan peternak atau keluarga }\end{array}$ & & & & .13 & & & -.10 & .78 & .10 & -.14 & \\
\hline Ketersediaan lahan milik & -.13 & .18 & & & & .48 & .15 & .52 & -.31 & .12 & \\
\hline $\begin{array}{l}\text { Ketersediaan tenaga kerja } \\
\text { keluarga }\end{array}$ & .20 & & & .19 & & .47 & & .48 & & & -.24 \\
\hline Harga sapi induk pengganti & -.17 & & & & & & -.14 & & .75 & & \\
\hline $\begin{array}{l}\text { Ketersediaan sapi induk } \\
\text { pengganti }\end{array}$ & .17 & .34 & .19 & .11 & -.13 & .22 & & -.18 & .58 & & \\
\hline Harga-harga sewa lahan & & -.15 & & & & .11 & & & & -.76 & \\
\hline Harga daging sapi & & & & & .11 & -.10 & & & & & .85 \\
\hline Kontribusi pada variasi (\%) & 13.6 & 8.76 & 8.07 & 5.89 & 5.42 & 4.99 & 4.56 & 4.35 & 4.01 & 3.51 & 3.44 \\
\hline
\end{tabular}

Keterangan:

Bobot faktor (factor loadings) yang dipertimbangkan adalah yang lebih besar dari 0.5. 
koperasi merujuk pada susu dengan kualitas rata-rata. Hal ini menyebabkan sebagian peternak yang memproduksi susu kualitas lebih tinggi harus menerima harga yang lebih rendah, sementara sebaliknya dengan para peternak yang memproduksi susu dengan kualitas yang lebih rendah.

Ketenagakerjaan menjadi salah satu faktor yang sangat mempengaruhi berjalannya usaha sapi perah (F4). Faktor ini meliputi beberapa aspek yang saling berkaitan yaitu semakin menurunnya minat tenaga kerja di bidang peternakan, rendahnya ketersediaan tenaga kerja dan semakin tingginya standar upah tenaga kerja. Di wilayahwilayah pedesaan pada saat ini, jumlah tenaga kerja produktif pertanian atau peternakan cenderung semakin menurun karena bidang kerja non-pertanian dianggap dapat memberikan insentif lebih, seperti perdagangan dan perindustrian yang berada di perkotaan. Rendahnya ketersediaan tenaga kerja menyebabkan usaha sapi perah mengalami keterbatasan ekspansi. Begitupun dengan tenaga kerja keluarga (anggota keluarga) yang tidak lagi memiliki minat untuk meneruskan usaha sapi perah milik keluarganya sehingga diperkirakan akan berdampak pada keberlanjutan usahanya (F6). Sebagai indikasi, fakta menunjukkan bahwa di dalam 5 tahun terakhir ini terjadi penurunan jumlah peternak yang cukup signifikan di wilayah penelitian. Selain dilatarbelakangi oleh faktorfaktor di atas, kondisi kesehatan peternak juga sedikitnya memberikan kontribusi pada penurunan tersebut (F8).

Berbagai aspek yang bersifat eksternal juga menjadi faktor risiko bagi usaha sapi perah seperti aspek tuntutan standar kualitas oleh mitra usaha serta penentuan harga susu (F5) dan aspek daya saing usaha terhadap lainnya (F10, F11). Standar kualitas susu yang dituntut cenderung semakin meningkat sejalan dengan juga meningkatnya harga beli susu oleh mitra usaha. Namun bagi peternak rakyat, peningkatan kualitas memerlukan tambahan input dan kapital dengan jumlah yang signifikan. Sesuatu hal yang lazim bahwa sebagian besar peternak tidak memiliki peluang untuk melakukan hal tersebut karena keterbatasan sumberdaya, terutama lahan. Seperti yang telah dibahas sebelumnya, ketidaktersediaan lahan tidak saja berdampak pada aspek penyediaan pakan namun juga pada aspek lainnya seperti peningkatan skala usaha ataupun pengolahan limbah peternakan. Pada faktanya, aspek penanganan limbah ternak pada saat ini telah banyak memunculkan konflik dengan masyarakat non-peternakan non-pertanian. Dengan begitu, permasalahan pengelolaan limbah telah muncul menjadi salah satu faktor risiko yang signifikan bagi usaha sapi perah (F7).

\section{Model dan Simulasi Risiko pada Rantai Pasok Susu}

Pada dasarnya, seluruh risiko yang telah teridentifikasi diyakini memberikan pengaruh yang nyata terhadap setiap pengambilan keputusan oleh masingmasing agen di dalam sistem, meskipun hasil analisis menunjukkan bahwa besaran pengaruh tiap-tiap jenis risiko tersebut berbeda. Berdasarkan hal tersebut, model risiko di dalam penelitian ini ini hanya menyertakan faktor-faktor yang terhitung memiliki pengaruh paling besar terhadap pengembilan keputusan; yaitu pakan (F1), kualitas genetik dan reproduksi (F2) dan penentuan harga beli susu oleh koperasi (F3). Faktor-faktor risiko lainnya dianggap tetap (given).

Pengaruh keberadaan risiko terhadap pengambilan keputusan produksi besarta dampaknya dimodelkan melalui beberapa skenario. Terdapat empat skenario di dalam model ini, yaitu (i) skenario dasar (baseline); (ii) skenario rendahnya ketersediaan pakan; (iii) skenario intervensi peningkatan ketersediaan pakan; dan (iv) skenario perubahan tatacara pengujian dan penentuan harga susu. Setelah disimulasikan, setiap skenario akan menghasilkan berbagai parameter yang merupakan indikasi bagi pengaruh risiko terhadap kinerja produksi para pelaku di dalam rantai pasok. Parameter yang dihasilkan di bawah skenario baseline merupakan nilai-nilai kinerja "tanpa risiko"; yang menjadi tolok ukur pembeda bagi nilai-nilai parameter yang dihasilkan di bawah skenario-skenario lainnya.

Tabel 2. Hasil simulasi pada berbagai skenario faktor risiko

\begin{tabular}{|c|c|c|c|c|}
\hline \multirow{2}{*}{ Parameter } & \multicolumn{4}{|c|}{ Skenario } \\
\hline & So & S1 & $\mathrm{S} 2$ & $\mathrm{~S} 3$ \\
\hline $\begin{array}{l}\text { Jumlah Peternak } \\
\text { (rumah tangga) }\end{array}$ & 22 & 7 & 12 & 20 \\
\hline $\begin{array}{l}\text { Rata-rata skala } \\
\text { usaha ternak } \\
\text { (ekor) }\end{array}$ & 0.77 & 0.57 & 1.66 & 0.9 \\
\hline $\begin{array}{l}\text { Produktivitas } \\
\text { ternak (liter/ } \\
\text { ekor) }\end{array}$ & 16.1 & 19.54 & 18.9 & 17.7 \\
\hline $\begin{array}{l}\text { Kualitas Susu } \\
(\%)\end{array}$ & 93.6 & 86 & 98 & 99.5 \\
\hline $\begin{array}{l}\text { Kondisi finansial } \\
\text { peternak (Rp) }\end{array}$ & 27,100 & 38,200 & 63,600 & 26,000 \\
\hline $\begin{array}{l}\text { Jumlah susu } \\
\text { yang dibeli } \\
\text { koperasi (liter) }\end{array}$ & 155 & 68 & 187 & 144 \\
\hline $\begin{array}{l}\text { Kondisi finansial } \\
\text { koperasi (Rp) }\end{array}$ & 369,000 & 294,000 & 172,000 & 397,000 \\
\hline
\end{tabular}

Keterangan:

$\mathrm{S} 0$ = skenario dasar; $\mathrm{S} 1$ = skenario rendahnya ketersediaan pakan; $\mathrm{S} 2$ = skenario peningkatan ketersediaan pakan; S3 = skenario perubahan metode penentuan harga susu.

Nilai parameter yang tercantum di dalam tabel bukan merupakan nilai faktual, melainkan hanya indikasi untuk melihat arah perubahan nilai (tetap, naik atau turun).

Berdasarkan hasil simulasi, terdapat perbedaan parameter yang cukup nyata antara skenario dasar yang mewakili kondisi aktual dan skenario lainnya. Pada skenario pertama yang menggambarkan situasi ketersediaan pakan yang rendah, sebagian besar nilai parameter mengalami penurunan kecuali produktivitas ternak dan finansial peternak. Kondisi ini dapat menggambarkan bahwa rendahnya ketersediaan pakan 
di dalam jangka panjang berpotensi untuk menyebabkan terjadinya penurunan jumlah peternak dan juga populasi sapi perah. Hal ini diikuti juga dengan turunnya jumlah pasokan susu dari peternak kepada koperasi yang berkonsekuensi pada turunnya pendapatan finansial koperasi. Sementara beberapa parameter menunjukkan kecenderungan yang meningkat seperti produktivitas dan kondisi finansial di tingkat peternak. Hal ini menggambarkan bahwa di dalam situasi berkurangnya ketersediaan pakan, usaha sapi perah yang dapat bertahan adalah mereka yang memiliki ternak dengan produktivitas tinggi.

Berkaitan dengan skenario pertama, skenario ke dua menggambarkan upaya-upaya untuk mengelola risiko melalui peningkatan ketersediaan pakan terutama pakan hijuan terutama oleh koperasi. Di dalam skenario ini, kondisi rendahnya ketersediaan pakan hijauan diintervensi melalui penyediaan hijauan oleh koperasi untuk para peternak. Hasil menunjukkan bahwa kecenderungan turunnya jumlah peternak masih tetap terjadi di dalam jangka panjang namun dengan laju yang lebih lambat dibandingkan skenario tanpa intervensi. Skenario ini juga memperlihatkan bahwa intervensi peningkatan penyediaan pakan berdampak positif terhadap berbagai parameter seperti skala usaha dan produktivitas ternak serta kuantitas dan kualitas susu yang dihasilkan oleh para peternak, namun sebagai konsekuensinya, kondisi finansial koperasi akan mengalami penurunan karena terdapatnya tambahan biaya di dalam memproduksi dan menyediakan pakan hijauan tersebut.

Skenario ke tiga menggambarkan perubahan metode penentuan harga susu yang dibeli oleh koperasi dari para peternak. Sebelumnya, penentuan harga susu didasarkan pada hasil pengujian kualitas susu di tingkat kelompok, maka pada skenario ini, pengujian susu dilakukan secara individu sehingga menghasilkan harga susu yang berbeda-beda antara satu peternak dan peternak lainnya. Di dalam jangka panjang, perubahan ini memberikan dampak cukup positif terhadap keberlangsungan rantai pasok susu. Dampak yang cukup penting adalah semakin lambatnya laju penurunan jumlah peternak serta meningkatnya skala usaha, produktivitas ternak dan kualitas susu yang cukup signifikan. Sejalan dengan itu, kondisi finansial koperasi pun cenderung meningkat karena meskipun kuantitas pembeliannya mengalami penurunan namun dengan kualitas susu yang meningkat. Meskipun begitu, terdapat kemungkinan di dalam jangka panjang terjadi penurunan tingkat pendapatan peternak secara umum. Hal ini dimungkinkan karena pada skenario ini perubahan metode penentuan harga tidak disertai dengan upaya lainnya yang berkaitan dengan pengelolaan risiko ketersediaan pakan, sehingga dampak positif dari perbaikan harga susu tidak dapat mengkompensasi dampak negatif dari rendahnya ketersediaan pakan.

Seluruh hasil simulasi dapat menunjukkan bahwa kinerja produksi rantai pasok susu sangat berkaitan dengan keberadaan risiko-risiko di dalamnya. Rendahnya ketersediaan pakan sebagai salah satu risiko yang utama secara jelas menyebabkan terjadinya penurunan kinerja produksi pada seluruh pelaku di dalam rantai pasok susu. Namun begitu, terdapatnya upaya untuk mengelola risiko melalui peningkatan ketersediaan pakan oleh pihak koperasi ternyata sangat berpotensi untuk menghambat laju penurunan kinerja produksi tersebut, baik pada tingkat peternak ataupun koperasi itu sendiri. Sejalan dengan hal ini, pengelolaan risiko kelembagaan melalui perubahan tatacara penentuan harga susu juga memberikan dampak perlambatan penurunan kinerja rantai pasok secara keseluruhan.

Skenario-skenario di atas hanya menggambarkan sebagian kecil risiko yang dihadapi oleh para pelaku rantai pasok susu. Seperti yang telah teridentifikasi, masih banyak terdapat banyak faktor-faktor risiko yang sangat mungkin terinternalisasi kepada setiap pengambilan keputusan produksi, serta menghasilkan dampak (outcome) yang berbeda-beda bagi setiap pelaku ataupun pada rantai pasok secara keseluruhan. Selain itu, setiap faktor risiko yang berada di dalam rantai pasok sapi perah diyakini tidak berdiri sendiri, melainkan berkaitan antara satu dan lainnya. Hal ini berarti bahwa terdapat banyak kombinasi antar faktor-faktor risiko yang memberikan derajat pengaruh yang berbeda-beda antar kombinasi. Oleh karena itu, diperlukan lebih banyak skenario untuk mengidentifikasi dan merancang bentuk-bentuk pengelolaan risiko lainnya yang sekiranya dapat menjadi pendorong utama penguatan kinerja produksi rantai pasok susu secara keseluruhan.

\section{SIMPULAN}

Secara umum, penelitian ini menemukan bahwa pada saat ini terdapat setidaknya sebelas faktor yang menjadi sumber utama risiko bagi usaha sapi perah ataupun rantai pasok susu secara keseluruhan. Di antara sekian banyak sumber risiko tersebut, keterbatasan daya dukung sumberdaya alam terutama di dalam ketersediaan dan pasokan input pakan menjadi sumber risiko yang dianggap paling penting oleh para pelaku usaha. Meskipun begitu, keberadaan risiko lainnya dalam mempengaruhi kinerja produksi para pelaku rantai pasok juga tidak dapat terabai. Penelitian ini juga menemukan kondisi dimana sebagian besar sumber risiko saling berkorelasi antara satu dan lainnya, sehingga risiko yang dihadapi oleh para pelaku rantai pasok susu diyakini tidak berdiri sendiri melainkan bersifat sistemik. Hal ini berimplikasi pada pengelolaan risiko yang tidak dapat dilakukan secara parsial melainkan harus bersifat holistik dan terintegrasi di dalam sebuah rantai pasok. Pengelolaan risiko yang holistik dan tersistem sangat dibutuhkan karena kinerja produksi yang dihasilkan oleh salah satu pelaku di bawah keberadaan risiko tertentu akan sangat menentukan kinerja pelaku lainnya, serta pada gilirannya akan menentukan kinerja rantai pasok susu secara keseluruhan. 
Di dalam konteks ini, para pelaku dan pihak-pihak lainnya yang berkepentingan dengan rantai pasok susu tentunya memerlukan alat bantu untuk merancang model pengelolaan risiko yang bersifat sistemik tersebut. Penelitian ini telah memperlihatkan sebagian kecil kemampuan "pemodelan berbasis agen" dalam mengkarakterisasi pengaruh berbagai risiko terhadap pengambilan keputusan oleh para pelaku serta memperkirakan dampaknya terhadap kinerja produksi. Oleh karena itu, melalui pemodelan ini, para pengambil kebijakan dapat terlebih dahulu melakukan uji-coba terhadap suatu rancang bangun model pengelolaan risiko sebelum diaplikasikan ke dalam dunia nyata. Untuk penelitian-penelitian selanjutnya, pemodelan berbasis agen diharapkan dapat dimanfaatkan untuk mengelaborasi model-model pengelolaan risiko sistemik yang menyertakan seluruh pelaku di dalam rantai pasok susu.

\section{DAFTAR PUSTAKA}

Abdi, H., \& Williams L.J. (2010). Principal component analysis, interdisciplinary reviews. Computational Statistics, 2(4), 433-459.

Akcaoz, H., Kizilay H., \& Ozcatalbas, O. (2009). Risk management strategies in dairy farming: a case study in Turkey. Journal of Animal and Veterinary Advances, 8(5), 949-958.

Chen, X., Ong Y.S., Tan P.S., Zhang N., \& Li Z. (2013). Agent based modeling and simulation for supply chain risk management - a survey of the state of the art. Proceeding of IEEE International Conference on System, Man and Cybernetics, Manchaster United Kingdom, 1294-1299.

Chow, W. (2004). An exploratory study of the success factors for extranet adoption in E-supply chain. Journal of Global Information Management, 12(1), 60-67.

Daud, A.R., Putro U. S., \& Utomo D. S. (2013). Employing agent based simulation to understand the behavior of domestic cattle production. Sosiohumaniora, 15(3), 319-328.
Daud, A.R., Putro U. S., \& Basri M.H. (2015). Risks in milk supply chain; a preliminary analysis on smallholder dairy production. Livestock Research for Rural Development, 27, Article \#137. http://www.lrrd.org/lrrd27/7/daud27137. htm.

Flaten, O., Lien G., Koesling M., Valle P.S., \& Ebbesvik M. (2005). Comparing risk perceptions and risk management in organic and conventional dairy farming: empirical results from Norway. Livestock Production Science, 95, 11-25.

KPBS (2016). Buku Laporan Tahunan, tahun buku 2016. Koperasi Peternak Bandung Selatan, Pangalengan Kabupaten Bandung.

Macal, C.M., \& North N.J. (2008). Tutorial on agent based modeling and simulation. Journal of Simulation, 4(3), 151-162.

Mauludin, M. A. (2017). Pengembangan peternakan sapi perah dan dinamika moda produksi usaha peternakan sapi perah di Pangalengan Jawa Barat. Sosiohumaniora, 19(1), 23-31.

Meuwissen, M.P.M., Huirne R.B.M., \& Hardaker J.B. (2001). Risk and risk management: an empirical analysis of Dutch livestock farmers. Livestock Production Science, 69, 43-53.

Mishra, P.K., \& Shekhar B.R. (2011). Impact of risks and uncertainties on supply chain: a dairy indutry persepective. Journal of Management Research, 3(2), 1-18.

Saunders, M., \& Lewis P. (2012). Doing research in business and management; an essential guide to planning your project. Essex, England. Financial Times Prentice Hall.

Zhou, H., Nanseki T., \& Takeuchi S. (2012). Dairy farmers' risk perception and risk management in China - evidence from Hebei Province and Inner Mongolia. Agricultural Information Research, 21(2), 20-27. 